DOI: $10.20472 / E S .2017 .6 .1 .003$

\title{
STRATEGIC BEHAVIOR AS THE CAUSE OF BUSINESS CYCLES
}

\section{JAN VORLICEK, KLARA CERMAKOVA}

\begin{abstract}
:
This paper is aimed to present theory of "natural strategic cycles" showing that the cyclical development of economic performance (among other causes economic theory has been processed) can be caused also by cyclical evolution of the proportions of various strategies used by different actors in society. We use game theory as theoretical background. The existence of various games gives us an explanation of why there are so many different cycles with different duration. We assume that the theory of strategic cycle can be used to explain e.g. speculative bubble on stock exchange or long-term cycles that are still somehow difficult to grasp.
\end{abstract}

\section{Keywords:}

Business cycles, strategic cycles, games theory

JEL Classification: C71, E03

\section{Authors:}

JAN VORLICEK, College of Business and Law, Czech Republic, Email: j.h.vorlicek@seznam.cz KLARA CERMAKOVA, University of Economics in Prague, Czech Republic, Email:

klara.cermakova@vse.cz

\section{Citation:}

JAN VORLICEK, KLARA CERMAKOVA (2017). Strategic Behavior as the Cause of Business Cycles . International Journal of Economic Sciences, Vol. VI(1), pp. 33-40., 10.20472/ES.2017.6.1.003 


\section{INTRODUCTION}

As we noted in our previous text (Vorlicek, Cermakova, 2015) it is possible to group business cycles into several categories according to different causes of their origin. We assume that the cause of business cycle can also be a strategic behavior of economic subjects, ergo strategic behavior of economic subjects during their mutual interaction. We think that it is possible to group strategic cycles into two categories, namely:

1. Institutional or collective strategic cycle, where the cause of business cycle are certain social institutions. So they would not exist in different arrangement of society. This can be case of for example monetary cycle which is also called Austrian Business Cycle Theory or budgetary cycle which is also called political or electoral cycle in economic literature.

2. Natural or individual strategic cycle, which is caused by strategic behavior of individuals in society. We can include under our theory of natural strategic cycle some of the older theories, which formal apparatus does not give such good options to formulate strategy using the game theory, which did not even exist when they were created. Nowadays, they are considered marginal in economic theory. Particularly the Marxist Cycle Theory - in modern times represented by Goodwin model and speculative cycle theory, which explains business cycle based on credit cycle theory, which is based on Irving Fisher's hypothesis of debt deflation and on Hyman Minsky's hypothesis of financial instability. We can also add M. Kalecki's cycle theory and many others in this group.

\section{NATURAL STRATEGIC CYCLES}

If all types of cycles (including institutional strategic cycles) that are presented in economy textbooks can be explained by traditional methods of economic analysis, then clarification of natural strategic cycles is possible thanks to the game theory.

Although the game theory is very mathematical discipline a simple mathematical apparatus will suffice our needs. Principle of natural strategic cycles can be summarized in single sentence:

Cyclical development of the ratio of different strategies used by individual subjects causes the cyclical development of performance of the society.

Validity of this sentence (i.e. That the ratio of strategies represented in society cyclically changes and along with it the performance of the society) is shown later on example in which we work with traditional terms of game theory such as game, player, payoff, strategy and population which is understood as the set of all players who play the game. By the evolution of the game we indicate the time development of portions of different strategies used in population. 
As the simplest possible example we will use a population which members only use two strategies, which we will call a dove and a hawk. Imagine for the illustration that they are actually two bird species whose members fly around possible hunting grounds and compete individually for them. During their mutual encounter members of each species chose different strategies - doves are peaceful and they would rather share the territory, the hawks are aggressive and they choose conflict over peace, which ends with one victor that gets the whole territory for himself, and one looser that has to leave and usually ends up wounded. Size of the rent (profit) of whole territory will be further named as $R$, amount of damage caused by pain as B. So if two doves meet, territory will be shared and each dove gets half of the profit $(1 / 2 R)$. But if two hawks meet, there will be only one winner getting whole profit from the territory $(R)$ and one looser suffering the damage from the wound $(B)$ - and since the capabilities of each individuals in our simplified example are exactly the same there is same chance of winning $-50 \%$. Which means that hawk is getting whole profit $\mathrm{R}$ in $50 \%$ of cases and in the other $50 \%$ of cases he is suffering the damage B. The average long-term profit of each hawk from encountering another hawk is therefore $1 / 2(R-B)$. In case that dove meets hawk, the peaceful dove will refuse to fight and she will leave the territory to hawk which means that hawk is getting the whole profit without a fight and without a risk. Dove is not getting anything and what is important she is not suffering any damage or loss like in case of hawk that loses the fight. You can see the situation clearly in the following table:

\begin{tabular}{|l|l|c|c|}
\hline \multirow{2}{*}{ Cooperation: } & \multicolumn{2}{|c|}{ subject B } \\
\cline { 3 - 4 } & Yes (dove) & No (hawk) \\
\hline \multirow{2}{*}{ subject A } & Yes (dove) & $1 / 2 R: 1 / 2 R$ & $0: R$ \\
\cline { 2 - 4 } & No (hawk) & $R: 0$ & $1 / 2(R-B): 1 / 2(R-B)$ \\
\hline & & & \\
\hline
\end{tabular}

In case the damage from fights is relatively low, specifically if they are lower or equal to total profit of the territory (therefore $B \leq R$ ), then there is no room for dove's strategy in the population. But on contrary, in case the damage is relatively high, specifically if it is higher than the total profit from whole territory (therefore $B>R$ ), then the strategy of hawk is too costly and its success is dependent on the fact that he rips off some dove from time to time - this strategy will appear in population just in ratio $\mathrm{R} / \mathrm{B}$. It is obvious that the higher the cost of conflict, the less will hawk strategy appear and the more will dove strategy appear in the population. This applies only for large population (infinite population is used in theory, but in practice it works on population that has at least 100 individuals). Mathematical proof of this claim can be found in e.g. (Chvoj, M., 2013).

If we were living in world with zero transaction cost (especially with perfect information and with zero cost for a change of strategy), there would be stabilized portion of hawks in population as mentioned above in value of $\mathrm{R} / \mathrm{B}$, from which it would not deviate. In world with non- 
zero transaction cost i.e. our world, it is not so and the portion of individual strategies will fluctuate around the equilibrium value. So let us base our interpretation of this phenomenon on assumption that there are fewer hawks than the equilibrium R/B in population - in this case it is viable for doves to leave their strategy and start using hawk's strategy. But in this case it is obviously impossible to turn a dove into a hawk, but hawks reproduce faster than doves in this kind of population. If there were zero transaction costs, the growth in portion of hawks on population would stop at $\mathrm{R} / \mathrm{B}$ ratio. In practice, where there are nonzero transaction costs, it is impossible to recognize value of $R / B$ and more and more subjects keep switching from dove strategy to hawk strategy. The fact that there are more hawks than it is sustainable in long-term is recognized with a delay. After recognition of the fact we are going to see the opposite process, therefore switching from now less effective hawk strategy to now more effective dove strategy. Even this process has its inertia in nonzero transaction costs world, which increases the portion of doves above long-term sustainable ratio, which is also recognized with a delay, and there starts the opposite process again, etc., etc. When we work with nonzero transaction costs which results in delays, we get the population in which there is unstable portion of different strategies. The ratio of used strategies fluctuates around equilibrium value.

Until now we did not come with something that has not been well described in game theory yet. But we have not heard yet that somebody used these consequent results to explain business cycles, like we do here now. For better illustration we will add specific numbers into the matrix that was mentioned above, e.g. $R=2$ a $B=4$ and we get this matrix:

\begin{tabular}{|l|l|c|c|}
\hline \multirow{2}{*}{ Cooperation: } & \multicolumn{2}{|c|}{ subject B } \\
\cline { 2 - 4 } & Yes (dove) & No (hawk) \\
\hline \multirow{2}{*}{ subject A } & Yes (dove) & $1: 1$ & $0: 2$ \\
\cline { 2 - 4 } & No (hawk) & $2: 0$ & $-1:-1$ \\
\hline
\end{tabular}

Equilibrium ratio of doves and hawks in these conditions will be $1: 1$. Average outcomes of their mutual encounters are shown in this payoff matrix:

\begin{tabular}{|l|r|r|r|}
\hline Strategy: & Dove & Hawk & Average \\
\hline Dove & 1 & 0 & 0,5 \\
\hline Hawk & 2 & -1 & 0,5 \\
\hline
\end{tabular}

Numbers in first two columns show how many "points" is the strategy in row getting when encountering one of the strategies in columns. Number in last column shows how much "points" is strategy getting on average in each encounter. Assuming that we play large number of rounds and that there is big amount of individuals in population, then all strategies 
meet directly proportional to ratio in which they are represented in population and by measuring values in this column we can also compare relative success of each strategy.

Imagine further that numbers mentioned above show amount of product, which given subject creates. Let's say that the ratio of hawks and doves in population fluctuates around plus minus $10 \%$ - so when we experience overpopulation of doves, there are $55 \%$ of doves in population and only $45 \%$ of hawks. It is the other way around in case of overpopulation of hawks. Let's see now, how the performance of each strategy and the total product of society changes due to fluctuation of ratio of doves and hawks in population around equilibrium value, as we discussed above.

Payoff matrix:

\begin{tabular}{|l|l|l|l|}
\hline Ratio dove : hawk (in \%) & $45: 55$ (crisis) & $50: 50$ & $55: 45$ (boom) \\
\hline Average performance of dove & 0,45 & 0,5 & 0,55 \\
\hline Average performance of hawk & 0,35 & 0,5 & 0,65 \\
\hline $\begin{array}{l}\text { Relative performance of population (in } \\
\%)\end{array}$ & 79 & 100 & 119 \\
\hline
\end{tabular}

Here is described the method how we calculated the values in table above: Imagine population as big as population of e.g. the Czech Republic (ten million individuals), while every individual encounters other 20 randomly selected individuals out of the same population.

If there are (as shown in first column in the outcome matrix) $45 \%$ doves and $55 \%$ hawks in population, then everyone will meet 9 doves and 11 hawks on average. Every dove will get 9 points from these encounters $(1 \times 9+0 \times 11-$ i.e. 1 for encountering each of 9 doves and 0 for encountering each of 11 hawks), i.e. on average 0,45 points from each encounter (9/20). Each hawk gets 7 points $(2 \times 9+-1 \times 11-$ i.e. 2 for encountering each of 9 doves and -1 for encountering each of 11 hawks), on average 0,35 points (7/20) from each encounter. Total product of these encounters will be $158(9 \times 9+7 \times 11-9$ for each out of 9 doves and 7 for each out of 11 hawks).

If there are (as shown in middle column) $50 \%$ (i.e. five million) doves and $50 \%$ (i.e. five million) hawks in population, everyone will meet 10 doves and 10 hawks on average. Every dove will get 10 points from these encounters $(1 \times 10+0 \times 10-$ i.e. 1 for encountering each of 10 doves and 0 for encountering each of 10 hawks), i.e. on average 0,5 points from each encounter (10/20). Each Hawk gets 10 points $(2 \times 10+-1 \times 10-$ i.e. 2 for encountering each of 10 doves and -1 for encountering each of 10 hawks), on average 0,5 points (10/20) from each encounter. Total product of these encounters will be $200(10 \times 10+10 \times 10-10$ for each out of 10 doves and 10 for each of 10 hawks) - this total product of society in equilibrium state is used as base (i.e. $100 \%$ ) in table above. 
And if there are (as shown in last column), $55 \%$ (i.e. five and a half million) doves and $45 \%$ (i.e. four and a half million) hawks in population, everyone will meet 11 doves and 9 hawks on average. Every dove will get 11 points from these encounters $(1 \times 11+0 \times 9-$ i.e. 1 for encountering each of 11 doves and 0 for encountering each of 9 hawks), i.e. on average 0,55 points from each encounter (11/20). Each hawk gets 13 points $(2 \times 11+-1 \times 9-$ i.e. 2 for encountering each of 11 doves and -1 for encountering each of 9 hawks), on average 0,65 points for each encounter (13/20). Total product of these encounters will be $238(11 \mathrm{x}$ $11+13 \times 9$ - i.e. 11 for each out of 11 doves and 13 for each out of 9 hawks).

The table above briefly sums up consequences of fluctuation of state of population of mentioned game around equilibrium state (which is mentioned in middle column) As we can see, if there are more hawks than doves in the population (left column in the outcome matrix), the output of each individual strategy is lower and therefore the total product is lower than in the equilibrium state. Output of dove is relatively higher than the performance of hawk (dove will reproduce faster in the population). On the contrary, if there are more doves than hawks in the population (right column in the outcome matrix), the output of each individual strategy is higher and therefore total product is higher than in the equilibrium state. However, the output of hawk is now relatively higher than output of dove (in this case it will be the hawk that will reproduce faster than dove in population). As we can see, economy of this population goes through cycle, while boom phase (growth of product) is caused by increase in portion of cooperative doves (and decline in portion of hawks) on population. The recession (decline of product) is caused by decline in portion of doves (and increase in portion of hawks) in population. Crisis (bottom of the cycle, i.e. the lowest performance of economy) is a period, where the portion of doves on population is on its minimum (and portion of hawks on population is at its maximum).

\section{CONCLUSION}

As shown above, it is clear that the ratio of individual strategies that are used in population influence the performance of society, therefore cyclical changes of this ratio necessarily cause fluctuations of total product of society. Interesting question is that why nobody came up with this conclusion before, even though game theory exists as separate systematic methodological approach to analysis of economic phenomenon for 70 years and there are many scientists using this approach in their work. It is probably because this theory is somehow outside current paradigm, which focuses on analysis of behavior of players in game but not on analysis of society as whole (Heritage of Austrian economic school is probably the cause, because of its skepticism to summing up individual utilities into societal aggregate).

Human society is obviously much more complicated than the model shown above. Nevertheless, in our opinion, the conclusion of this model can still be applied. Situations in which people find themselves do not always look like our game above, but they also look like many others e.g. stag hunt, prisoner's dilemma, or battle of sexes. There aren't just two strategies that people can use (esp. in so. repeated games). There are actually much more strategies than just two (e.g. spiteful strategy, loan in return, etc.), which obviously complicates the 
analysis. The existence of various games could give us an explanation to why there are so many different cycles with different duration. We assume that the theory of strategic cycle can be used to explain e.g. speculative bubble on stock exchange (following the successful strategy until overpopulation) or e.g. long-term cycles that are still somehow difficult to grasp (there are various strategies across generations due to different conditions that every generation had while creating their long term strategy), etc.

\section{References:}

Chvoj, M.: Pokročilá teorie her ve světě kolem nás, Grada, Praha, 2013, str. 46-48

Fisher, I.: The Debt-Deflation Theory of Great Depressions, Econometrica 1, 1933, p. 337-57

George, H.: Progress and Poverty: An Inquiry into the Cause of Industrial De pressions and of Increase of Want with Increase of Wealth; The Remedy, Robert Schalkenbach Foundation, New York, 1935.

Goodwin, R. M.: A Growth Cycle, in: Socialism, Capitalism and Economic Growth, Cambridge, Cambridge University Press, 1967

Hayek, F. A.: Monetary Theory and Trade Cycle, Sentry Press, New York, 1933

Hayek, F. A.: Prices and Production, Macmillan, London, 1931

Juglar, C.: Des Crises Commerciales..., Guillaumin, Paris, 1862.

Kalecki, M.: Selected essays on the dynamics of the capitalist economy, Cambridge, Cambridge University Press, 1971

Keen, S.: Finance and economic breakdown: modelling Minsky's Financial Instability Hypothesis, Journal of Post Keynesian Economics, Vol. 17, No. 4, 1995, p. 607-635

Kitchin, J.: Cycles and Trends in Economic Factors, Review of Economic Statistics 5, 1923, p. 10 - 16.

Kondratieff, N. D.: The Long Waves in Economic Life, The Review of Economic Statistic 17/6, 1935, p. $105-115$

Kuznets, S.: Secular Movements in Production and Prices, Houghton Miffin, Boston, 1930.

Kydland, F. E., Prescott, E. C.: Business Cycles: Real Facts and Monetary Myth, Quarterly Review, Federal Reserve Bank of Mineapolis, Spring 1990

Kydland, F. E., Prescott, E. C.: Time to Build and Aggregate Fluctuations, Econometrica 50, 1982, p. $1345-1371$

Lucas, R. E.: Models of Business Cycles, Basil Blackwell, Oxford, 1987

Mankiw, N. G.: Real Business Cycles: A New Keynesian Perspective, The Journal of Economic Perspectives 3, 1989, p. 79-90.

Marx, K.: Capital: A Critique of Political Economy - Volume III: The Process of Capitalist Production as a Whole, Charles H. Kerr and Co. Cooperative, Chicago, 1909 
Minsky, H. P.: The Modeling of Financial Instability: An introduction, in: Modeling and Simulation. Proceedings of the Fifth Annual Pittsburgh Conference 5, 1974

Mises, L.: The Theory of Money and Credit, Yale University Press, New Haven, 1953

Nash, J.: Equilibrium points in $n$-person games, in: Proceedings of the National Academy of Sciences of the United States of America 36 (1), 1950, p. 48-49

Neumann, J., Morgenstern, O.: Theory of Games and Economic Behavior, Princeton University Press, 1944

Nordhaus W. D.: The Political Business Cycle, Review of Economic Studies, vol. 42, 1975, p. 169-190

Quesnay, F.: Maximes Générales du Gouvernement Économique d'un Royaume Agricole ..., in: Physiocratie ..., Paris, 1768

Ridley, M.: The Origins of Virtue: Human Instincts and the Evolution of Cooperation, Penguin Books, London, 1996

Samuelson, P. A., Nordhaus, W. D.: Economics, ed. 13., McGraw-Hill, New York, 1989

Samuelson, P. A.: Interactions between the multiplier analysis and the principle of acceleration, Review of Economic Statistics 21, 1939, p. 75-78

Schumpeter, J. A.: Business Cycles, McGraw-Hill, New York, 1939

Schumpeter, J. A.: The Theory of Economic Development, Harvard University Press, Cambridge, 1934

Tainter, J. A.: The Collapse of Complex Societies, Cambridge University Press, 1988

Tufte, E. R.: The Political Manipulation of the Economy: Influence of the Electoral Cycle on Macroeconomic Performance and Policy, Department of Politics, Princeton University, 1974

Vorlicek, J., Cermakova, K.: Marginalized Theories of Business Cycle based on Strategic Behavior, In: LÖSTER, Tomáš, PAVELKA, Tomáš (ed.). The 9th International Days of Statistics and Economics (MSED 2015) [online]. Praha, 10.09.2015 - 12.09.2015. Slaný: Melandrium, 2015, s. 17121725. ISBN 978-80-87990-06-3

Wicksell, K.: Interest and Prices, Macmillan, London, 1936

Wicksell, K.: Lectures on Political Economy, vol. 2., Routledge and Kegan Paul, London, 1935 